\title{
WORK ENVIRONMENT FACTORS IN AFFECTING EMPLOYEE PERFORMANCE
}

\author{
by \\ Dermawan Perangin Angin ${ }^{1}$, Marto Silalahi ${ }^{2}$, Marthin Hutler Ambarita ${ }^{3}$, \\ Sudung Simatupang ${ }^{4}$, Swendy Barus ${ }^{5}$ \\ 1,2,3,4,5Fakultas Ekonomi\ Universitas Simalungun, Sekolah Tinggi Ilmu Ekonomi Sultan Agung \\ Email: ${ }^{1}$ darmawanperanginangin78@ gmail.com, ${ }^{2}$ martosilalahi70@gmail.com, \\ ${ }^{4}$ marthinhutlerambarita@gmail.com,
}

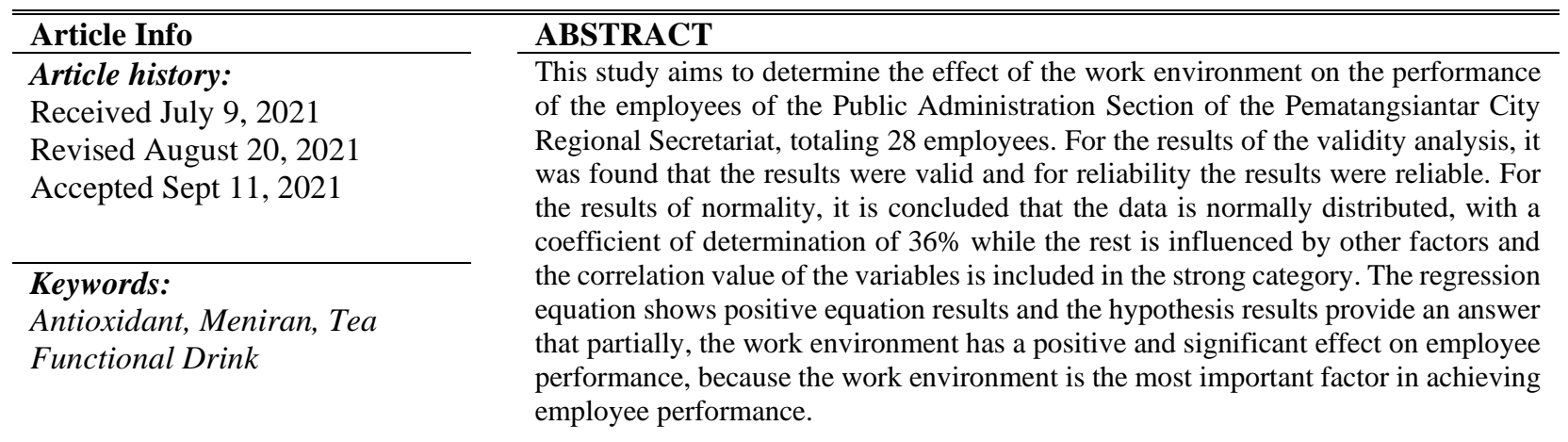

This is an open access article under the CC BY-SA license.

Corresponding Author:

Dermawan Perangin Angin

Fakultas Ekonomi, Universitas Simalungun, Sekolah Tinggi Ilmu Ekonomi Sultan Agung

Email: darmawanperanginangin78@gmail.com

\section{INTRODUCTION}

The dynamics of the success of any organization is to always want the wheels of the organization's life to grow and develop in accordance with the vision and mission of the organization and what is the foundation of controlling the success of the organization cannot be separated by the availability of human resources who have the ability to support this success, because human resources both from inside and outside the organization can be a parameter of the success of the organization (Pambudi, 2014) and human resources are one of the factors of organizational success or failure (Mulyono and Kresnaini, 2016). For this reason, it is highly expected that the human resources contained in the organization in this case the members of the organization have good performance, because as individuals in the organization to be able to survive it is necessary to show increased performance, because employees are the most valuable assets that must be considered and properly fostered so that institutions must pay attention to the details of programs with human resource development in order to produce employees who have high abilities and broad knowledge (Kurniawan and Heryanto, 2019) and employees need a work environment that supports employees in producing such performance because the work environment is everything that is around workers and influences them in carrying out their duties (Dhermawan, Sudibya and Utama, 2012).

Performance is an achievement of results or degree of accomplishment (Byars and Rue, 2006); Performance can be the ability of an individual to be able to carry out their duties in their place of work with the meaning of enthusiasm and have a healthy attitude (Nadeem and Ahmad, 2017), because with good performance, the organization will have an impact that is able to change the sustainability of the organization in a good direction, in other words, the performance of employees is a measure of the success of the organization in which they work. Likewise, the performance of employees from the Public Administration Section of the Pematangsiantar City Regional Secretariat

Journal homepage: https://bajangjournal.com/index.php/IJSS 
whose main task from the scope of their work is to provide services to regional apparatus so that the task of the government, government administration in fulfilling the needs of regional apparatus.

The performance of civil servants is regulated in (Government Regulation No. 30 concerning Performance Assessment of Civil Servants, 2019) which for employee performance is divided into two main targets, namely the Employee Work Target which consists of quantity, quality, time, and cost. While the Work Behavior which consists of service orientation, commitment, work initiative, cooperation and leadership. However, the phenomenon of employee performance is still not in line with expectations, where for employee work targets there are still employees who have not used working hours as well as possible so that many work results are neglected, for work behavior there are still employees who do not have the commitment to carry out discipline working hours during break time and not all employees who take part in the morning and afternoon ceremony every day and as a result services for employee administration are often neglected.

In achieving successful performance, one of the factors that can influence it is the work environment, in line with research (Liestiani et al., 2019); (Pawirosumarto, Bachelor and Gunawan, 2017) that the work environment has a positive influence on performance, then the work environment becomes aspects of work, work psychology, work regulations and comfort among co-workers and is able to affect employee performance (Mangkunegara, 2017) and consists of the environment work that is physical and non-physical in nature (Hidayati, Perizade and Widiyanti, 2019), because a comfortable and inclusive work environment will improve employee work so as to improve organizational performance (Nanzushi, 2015); 1

The working environment of the employees of the Public Administration Section of the Pematangsiantar City Regional Secretariat for the physical work environment consists of a workplace building, good work space, availability of work equipment, ventilation, rest areas, places of worship, and transportation facilities, then for the non-physical environment consists of : harmonious working relationship between employees and superiors. However, for the physical work environment, it was found that the feasibility of work equipment such as computer work equipment and printers that were no longer suitable for use but were still used by employees in carrying out their activities as well as for non-physical work environments, the working relationship between employees, superiors and subordinates showed that it was still less harmonious as at the time when the superior is in the room there is a rigid atmosphere between employees and superior at work,

This will certainly interfere with the work life of the organization and those who feel it the most are employees and will certainly affect employee performance. Because employee performance can be successful when the wheels of organizational life are not unequal in the work process, a little inequality, then performance will also change.

\section{LITERATURE REVIEW}

\section{Work Environment}

A successful organization cannot be separated from its ability to manage its environment, because to achieve its goals, the organization cannot be separated from its internal and external environment (Syahrulloh, 2021), the work environment can be considered only as an environment where people work, such as the physical setting and characteristics of the job itself (Briner, 2000) and the type of environment in which employees operate will determine the organization will succeed (Chandrasekar, 2011) then that the physical design of the office and the conditions of the workplace environment are important factors in organizational performance (Al-Omari and Okasheh, 2017)

\section{Employee Performance}

Performance is an important element of the organization's human resources, performance is the result of the quality and quantity of work achieved by an employee in carrying out their duties according to the responsibilities given to him (Bintoro and Daryanto, 2017). Performance can be interpreted as a description of the level of implementation of program activities or policies in realizing the goals, objectives, vision and mission of the organization contained in the organization's strategic planning (Moeheriono, 2012) and the willingness to excel explains that the aspirations of employees in placing work as a big struggle against their work (Eysenck, 1998).

\section{RESULTS AND DISCUSSION Validity Test}

The validity test is carried out by determining the criteria for valid data based on the accuracy of the data on the research object with the data reported by the researcher (Sugiono, 2019) and comparing the value of the correlation coefficient $>$ tcritical $=0.30$ (Barker, Pistrang and Elliott, 2016). For more details for the validity data, see the following table 
Vol.1 No.3 October 2021, pp: 203-208

ISSN: 2798-3463 (Printed) | 2798-4079 (Online)

DOI: https://doi.org/10.53625/ijjss.v1i3.413

Table 1. Validity Test

\begin{tabular}{|c|c|c|c|}
\hline Variables & $\begin{array}{c}\text { Corrected Item- } \\
\text { Total Correlation }\end{array}$ & rcritical & Criteria \\
\hline $\begin{array}{c}\text { Work } \\
\text { Environment }\end{array}$ &, 501 & 0,30 & Valid \\
\hline Performance &, 439 & 0,30 & Valid \\
\hline
\end{tabular}

The results from table 1 show that the value of the work environment correlation coefficient is 0.501 and the performance is 0.30 and the results show that the correlation coefficient value is $>$ rcritical 0.30 , which means the work environment and performance, the data criteria are valid.

\section{Reliability Test.}

Reliability is used to determine the extent to which the measuring instrument used is able to provide consistent measurements if repeated measurements are done (Brahmasari and Suprayetno, 2016) and by comparing the minimum reliability level of Cronbach's alpha > 0.70 (Eisingerich and Rubera, 2010). Reliability test results can be seen in the following table.

Table 2. Reliability Test

\begin{tabular}{|c|c|c|c|}
\hline Variables & $\begin{array}{c}\text { Cronbach's } \\
\text { Alpha } \\
\text { if Item Deleted }\end{array}$ & rcritical & Criteria \\
\hline $\begin{array}{c}\text { Work } \\
\text { Environment }\end{array}$ &, 900 & 0,70 & Reliable \\
\hline Performance &, 901 & 0,70 & Reliable \\
\hline
\end{tabular}

Table 2 shows the results of Cronbach's alpha value for the work environment variable is 0.900 and performance is 0.901 and the conclusion is that Cronbach's alpha value is > rcritical 0.70 which means that all variables are declared to have reliable criteria.

\section{Normality Test.}

Normality data testing is used to determine the distribution of data in the regression model, whether the confounding or residual variables have a confounder or not (Ghozali, 2016), and for more details, it can be seen in the following table.

Table 3. Normality

One-Sample Kolmogorov-Smirnov Test

\begin{tabular}{|cc|r|r|}
\hline & & $\begin{array}{c}\text { Work } \\
\text { Environment }\end{array}$ & Performance \\
\hline $\mathrm{N}$ & Mean & 28 & 28 \\
Normal & Std. & 38,39 & 76,46 \\
& Deviation & 4,701 & 7,105 \\
Most & Absolute &, 134 &, 131 \\
Extreme & Positive &, 114 &, 131 \\
Differences & Negative &,- 134 &,- 089 \\
&, 708 &, 692 \\
Kolmogorov-Smirnov Z &, 698 &, 724 \\
Asymp. Sig. (2-tailed) & &
\end{tabular}

a. Test distribution is Normal.

The results from table 3 show the asymp value. sig. (2-tailed) for the work environment variable is 0.698 and performance is $0.724>\operatorname{sig} \alpha 0.05$, which means that the work environment and performance data have a normal distribution.

\section{Coefficient of Determination}

The coefficient of determination is used to see how big the ability of the independent variable is in explaining the dependent variable and the results of the coefficient of determination can be seen in the following table. 
Vol.1 No.3 October 2021, pp: 203-208

ISSN: 2798-3463 (Printed) | 2798-4079 (Online)

Table 4. Coefficient of Determination

Model Summary ${ }^{b}$

\begin{tabular}{|c|r|r|r|r|}
\hline Model & $\mathbf{R}$ & $\begin{array}{c}\text { R } \\
\text { Square }\end{array}$ & $\begin{array}{c}\text { Adjusted } \\
\text { R Square }\end{array}$ & $\begin{array}{c}\text { Std. Error } \\
\text { of the Estimate }\end{array}$ \\
\hline 1 & $.608^{\mathrm{a}}$ &, 369 &, 345 & 5,751 \\
\hline
\end{tabular}

Table 4 shows the results for the RSquare value of 0.369 or $36 \%$, which means the ability of the work environment to explain employee performance is $36 \%$ while the remaining $64 \%$ are variables that are not discussed in this study, such as motivation, organizational culture and others. Then the value of $\mathrm{R}=.608$ means that the work environment has a strong relationship with performance.

\section{Simple Regression Equation}

Simple linear regression equation is used to see the relationship between one independent variable by having a straight relationship to the dependent variable then to see the results of the simple regression can be seen in the following table.

Table 5. Simple Regression Equation

Coefficients $^{\text {a }}$

\begin{tabular}{|c|c|c|c|c|c|c|}
\hline \multirow{2}{*}{\multicolumn{2}{|c|}{ Model }} & \multicolumn{2}{|c|}{$\begin{array}{l}\text { Unstandardized } \\
\text { Coefficients }\end{array}$} & \multirow{2}{*}{$\begin{array}{c}\begin{array}{c}\text { Standardiz } \\
\text { ed Coefficients }\end{array} \\
\text { Beta } \\
\end{array}$} & \multirow{2}{*}{$\mathbf{t}$} & \multirow[t]{2}{*}{ Sig } \\
\hline & & B & $\begin{array}{c}\text { Std. } \\
\text { Error }\end{array}$ & & & \\
\hline 1 & t) (Constan & $\begin{array}{r}41,21 \\
1 \\
\end{array}$ & 9,104 & & $\begin{array}{r}4,52 \\
7\end{array}$ & $\begin{array}{r}00 \\
0\end{array}$ \\
\hline & $\begin{array}{c}\text { Work } \\
\text { Environment }\end{array}$ & ,918 & ,235 & 608, & $\begin{array}{r}3,90 \\
0 \\
\end{array}$ & $\begin{array}{r}, 00 \\
1 \\
\end{array}$ \\
\hline
\end{tabular}

a. Dependent Variable: Performance

Table 5 is the result for a simple linear regression equation model whose result is $\mathrm{Y}=41.211+0.9178 \mathrm{X}$, and it means that if the result for the constant value is 41.211 that when the work environment value does not exist or 0 , then the value of employee performance is 41.211 and the value of regression coefficient is 0.918 that when 1 is added to the value of the work environment, the value of the employee performance variable will increase by 0.918 . Furthermore, the results of the equation show that the work environment has a positive influence on employee performance.

\section{Partial Hypothesis Test (t Test)}

Partial testing is used to determine that there is a partial effect on the independent and dependent variables by looking at the $\mathrm{t}$ value and the significance used is $5 \%$. To see the results of the partial hypothesis can be seen in the following table.

Table 6. Partial Hypothesis Test

\begin{tabular}{|c|c|r|r|}
\hline \multicolumn{2}{|c|}{ Model } & $\mathbf{t}$ & Sig. \\
\hline \multirow{2}{*}{1} & (Constant) & 4,527 &, 000 \\
\cline { 2 - 4 } & $\begin{array}{c}\text { Work } \\
\text { Environment }\end{array}$ & 3,900 &, 001 \\
\hline
\end{tabular}

Table 6 shows the results for the value of tcount $=3.900$ and the significance of the count $=0.01$ with the value of degrees of freedom $\mathrm{df}=\mathrm{n}(\mathrm{n}-2)=28-2=$ the result is ttable $=2.055$. Thus, it can be concluded that tcount $>$ ttable $=3.900>2.055$ and the significance value of $0.001<0.05$ means that accepting the hypothesis that there is a positive and significant influence from the work environment on employee performance.

Effect of Work Environment on Employee Performance.

The work environment of an organization can be a benchmark for the success of the performance of its members, because a good work environment (physical and non-physical environment) will make employees enthusiastic about work, the results of which will produce maximum employee performance. Research (Herawati, Minarsih and Malik, 
International Journal of Social Science (IJSS)

Vol.1 No.3 October 2021, pp: 203-208

ISSN: 2798-3463 (Printed) | 2798-4079 (Online)

DOI: https://doi.org/10.53625/ijss.v1i3.413

2020); (Badrianto and Ekhsan, 2020); (Putri et al., 2019) has a positive and significant effect on employee performance, but that the physical environment has no significant effect on performance, only psychosocial aspects and work-life balance factors are significant (Samson, Waiganjo and Koima, 2015) then the non-physical environment can also have an insignificant effect on performance (Norianggono, Hamid and Ruhana, 2014). This can happen when the atmosphere at work is not good, for example, the lighting which is deficient (dim) so that it can interfere with concentration at work, poor spatial planning also affects work results, then the non-physical environment has no effect when the relationship between subordinates and subordinates is not so harmonious. as well as superior-subordinate relationships. If this happens, it will interfere with organizational goals and directly or indirectly the impact will appear on performance, because the work environment is one of the most important components in influencing performance (Hafee et al., 2019).

\section{CONCLUSIONS}

The results of the study indicate that the work environment has a positive influence on performance, because the work environment, both physical and non-physical, is an important component that is able to produce the performance of the organizational members, in this case the employees to provide good work results as well.

Organizational leaders should pay attention to the work environment such as coloring, good lighting, spatial planning that is able to make employees feel comfortable to work and able to continuously maintain harmonization between superiors and subordinates and subordinates with subordinates.

\section{REFERENCES}

[1] Al-Omari, K. and Okasheh, H. (2017) 'The influence of work environment on job performance: A case study of engineering company in Jordan', International Journal of Applied Engineering Research, 12(24), pp. 1554415550.

[2] Badrianto, Y. and Ekhsan, M. (2020) 'EFFECT OF WORK ENVIRONMENT AND JOB SATISFACTION ON EMPLOYEE PERFORMANCE IN PT. NESINAK INDUSTRIES', Journal of Business, Management and Accounting, 2(1), pp. 85-91.

[3] Barker, C., Pistrang, N. and Elliott, R. (2016) Research Methods in Clinical Psychology: An Introduction for Students and Practitioners (3rd ed.). Edition: 3. England: John Wiley \& Sons Ltd. doi: 10.1002/9781119154082.

[4] Bintoro and Daryanto (2017) Manajemen Penilaian Kinerja Karyawan. Yogyakarta: Gava Media.

[5] Brahmasari, I. A. and Suprayetno, A. (2016) 'Pengaruh Motivasi Kerja, Kepemimpinan dan Budaya Organisasi Terhadap Kepuasan Kerja Karyawan serta Dampaknya pada Kinerja Perusahaan (Studi kasus pada PT. Concord Indonesia)', JURNAL MANAJEMEN DAN KEWIRAUSAHAAN, 10(2), pp. 124-135. doi: 10.36805/manajemen.v2i1.181.

[6] Briner, R. B. (2000) 'Relationships between work environments, psychological environments and psychological well-being.', Occupational medicine (Oxford, England). England, 50(5), pp. 299-303. doi: 10.1093/occmed/50.5.299.

[7] Byars, L. L. and Rue, L. W. (2006) Human Resource Management. Eighth Edi. McGraw-Hill/Irwin.

[8] Chandrasekar, K. (2011) 'Workplace Environment and Its Impact on Organisational Performance in Public Sector Organisations', International Journal of Enterprise Computing and Business Systems, 1(1), pp. 1-19.

[9] Dhermawan, A. A. N. B., Sudibya, I. G. A. and Utama, I. W. M. (2012) 'Pengaruh Motivasi, Lingkungan Kerja, Kompetensi, Dan Kompensasi Terhadap Kepuasan Kerja Dan Kinerja Pegawai Di Lingkungan Kantor Dinas Pekerjaan Umum Provinsi Bali', Jurnal Manajemen, Strategi Bisnis, dan Kewirausahaan, 6(2), pp. 173-184. Available at: https://ojs.unud.ac.id/index.php/jmbk/article/view/2203/1400.

[10]Eisingerich, A. B. and Rubera, G. (2010) 'Drivers of Brand Commitment: A Cross-National Investigation', Journal of International Marketing, 18(2), pp. 64-79. doi: 10.1509/jimk.18.2.64.

[11]Eysenck, M. W. (1998) Psychology: An Integrated Approach. New York: Addison-Wesley Longman Ltd.

[12] Ghozali, I. (2016) Aplikasi Analisis Multivariate Dengan Program IBM SPSS 23. Semarang: Badan Penerbit Universitas Diponegeoro.

[13] Hafee, I. et al. (2019) 'Impact of Workplace Environment on Employee Performance: Mediating Role of Employee Health', Business, Management and Education, 17(2), pp. 173-193. doi: 10.3846/bme.2019.10379.

[14] Herawati, P., Minarsih, M. M. and Malik, D. (2020) 'ANALYSIS OF INFLUENCE OF WORK LOAD, WORK DISCIPLINE, WORK ENVIRONMENT, AND WORK MOTIVATION EMPLOYEE PERFORMANCE (Study on the Service Sub Department of PT. Pos Indonesia (Persero) Semarang)', Journal of Management, 6(1), pp. 110. Available at: http://jurnal.unpand.ac.id/index.php/MS/article/view/1519. 
[15] Hidayati, S. K., Perizade, B. and Widiyanti, M. (2019) 'Effect Of Work Discipline And Work Environment To Performance Of Employees (Case Study at the Central General Hospital (RSUP) Dr. Mohammad Hoesin Palembang)', International Journal of Scientific and Research Publications (IJSRP), 9(12), pp. 391-398. doi: 10.29322/ijsrp.9.12.2019.p9643.

[16] Kurniawan, H. and Heryanto (2019) 'Effect of Work Discipline and Work Environment on Employee Performance with Work Motivation as an Intervening Variable in Department of Tourism, Youth and Sport of Padang District', Archives of Business Research, 7(7), pp. 88-101.

[17] Liestiani, N. L. et al. (2019) 'The Effect of Work Discipline and Work Environment on the Performance of AL Hudori Cooperative of Palembang Employees', Journal of Economics and Business, 2(1), pp. 61-72. doi: 10.31014/aior.1992.02.01.67.

[18] Mangkunegara, A. A. A. P. (2017) Manajemen Sumber Daya Manusia Perusahaan. Cet 14. Bandung: Remaja Rosdakarya.

[19] Moeheriono (2012) Pengukuran Kinerja Berbasis Kompetensi. Jakarta: PT. RajaGrafindo Persada.

[20] Mulyono, S. and Kresnaini, E. (2016) 'Memetakan Perubahan Organisasi Dalam Desain Learning Organization Pada Usaha Kecil Menengah di Kota Malang', Jurnal Ekonomi dan Bisnis, 18(1), p. 101. doi: 10.24914/jeb.v18i1.270.

[21] Nadeem, K. and Ahmad, A. (2017) 'Impact of Work Environment Factors on Employee Performance ; Empirical Evidence from Manufacturing Industry of Lahore', Manajemen Sciences, 11(03), pp. 422-436.

[22] Nanzushi, C. (2015) The Effect of Workplace Environment on Employee Performance in the Mobile Telecommunication Firms in Nairobi City County Cynthia Nanzushi a Research Project Submitted in Partial Fulfillment of the Requirements for the Award of the Degree of Master of Busi, International Business \& Economic Research Journal. UNIVERSITY OF NAIROBI.

[23] Norianggono, Y. C. P., Hamid, D. and Ruhana, I. (2014) 'PENGARUH LINGKUNGAN KERJA FISIK DAN NON FISIK TERHADAP KINERJA KARYAWAN (Studi Pada Karyawan PT. Telkomsel Area III Jawa-Bali Nusra di Surabaya)', Jurnal Administrasi Bisnis (JAB), 8(2), pp. 1-10.

[24]Pambudi, C. A. (2014) Organisasi yang Tumbuh Berkembang dan Menginspirasi, https://www.djkn.kemenkeu.go.id. Available at: https://www.djkn.kemenkeu.go.id/artikel/baca/6080/Organisasiyang-Tumbuh-Berkembang-dan-Menginspirasi.html (Accessed: 20 July 2021).

[25] Pawirosumarto, S., Sarjana, P. K. and Gunawan, R. (2017) 'The effect of work environment, leadership style, and organizational culture towards job satisfaction and its implication towards employee performance in Parador Hotels and Resorts, Indonesia', International Journal of Law and Management. Emerald Publishing Limited, 59(6), pp. 1337-1358. doi: 10.1108/IJLMA-10-2016-0085.

[26] Government Regulation Number 30 Concerning the Performance Assessment of Civil Servants (2019)

[27]Putri, E. M. et al. (2019) 'THE EFFECT OF WORK ENVIRONMENT ON EMPLOYEE PERFORMANCE THROUGH WORK DISCIPLINE', International Journal of Research - Granthaalayah, 7(4), pp. 132-140. doi: 10.5281/zenodo.2653144.

[28] Samson, N. G., Waiganjo, M. and Koima, J. (2015) 'the Effect of Workplace Environment on Employee Performance', International Journal of Managerial Studies and Research (IJMSR), 3(12), pp. 76-89.

[29] Sugiono (2019) Metode Penelitian Kuantitatif, Kualitatif, dan R\&D. Cetakan-1. Bandung: Alfabeta.

[30] Syahrulloh, R. J. (2021) LINGKUNGAN ORGANISASI, http://rjsyahrulloh.blogspot.com. Available at: http://rjsyahrulloh.blogspot.com/2016/02/lingkungan-organisasi.html (Accessed: 20 July 2021). 